\title{
Trash to treasure: assessing viability of wing biopsies for use in bat genetic research
}

\author{
Mary Beth Manjerovic • Michelle L. Green • \\ Andrew N. Miller · Jan Novakofski • \\ Nohra E. Mateus-Pinilla
}

Received: 18 February 2014/Accepted: 27 December 2014/Published online: 13 January 2015

(C) The Author(s) 2015. This article is published with open access at Springerlink.com

\begin{abstract}
The outbreak of white-nose syndrome in North American bats has resulted in massive data collection efforts to characterize the fungus, Pseudogymnoascus destructans. Wing biopsies routinely are collected from live bats, placed in agar media to culture the fungus, and ultimately discarded. We tested whether these discarded tissues represent a viable source of host bat DNA. We found no difference in DNA concentration and no reduction of DNA quality between samples that were extracted immediately compared to samples placed in agar for fungal culture. Although recovered quantities were low, concentrations increased using a cleanup kit. Our study suggests samples collected from live bats can be leveraged across disciplines to further our understanding of bat genetics and the impact of white-nose syndrome.
\end{abstract}

Keywords White-nose syndrome $\cdot$ Genetics $\cdot$ Bats $\cdot$ Biopsy $\cdot$ Fungal culture $\cdot$ DNA

White-nose syndrome (WNS) has killed millions of bats since it was first detected in 2006 (US Fish and Wildlife Service 2012), prompting efforts to collect samples to

M. B. Manjerovic · M. L. Green · J. Novakofski

Department of Animal Sciences, University of Illinois UrbanaChampaign, 1503 S. Maryland Drive, Urbana, IL 61801, USA

M. B. Manjerovic · M. L. Green · A. N. Miller ·

N. E. Mateus-Pinilla $(\square)$

Illinois Natural History Survey, University of Illinois UrbanaChampaign, 1816 S. Oak Street, Champaign, IL 61820, USA

e-mail: nohram@illinois.edu

Present Address:

M. B. Manjerovic

Lincoln Park Zoo, 2001 North Clark Street, Chicago, IL 60614, USA better understand this fungal outbreak. Sampling hibernating bats presents interesting challenges. Animals are slow moving and aggregated allowing for multiple samples from a small area. However, unnecessary arousals result in significant energy expenditures (Thomas et al. 1990; Speakman et al. 1991) so number of sampling events should be minimized. Sampling logistics are further complicated because humans can spread fungal spores and cave access often is restricted (US Fish and Wildlife Service 2011). Therefore, research efforts are constrained in the number of animals and locations that can be sampled and achieving required sample sizes is difficult.

The small size of bats must be considered when collecting tissue. Wing biopsies are routinely used for diagnostics and confirmation of WNS. Federal guidelines recommend no more than two, 3-5 mm wing punches should be taken from each bat (http://www.nwhc.usgs.gov/disease_information/whitenose_syndrome/USGS_NWHC_Bat_WNS_submission_ protocol.pdf). The USGS National Wildlife Health Center recommends using one biopsy from each wing to detect fungal presence either through direct culture or PCR methods, precluding additional genetic sampling.

To maximize tissues collected from live bats, we determined if samples collected for $P$. destructans research can be utilized for additional research projects on bat genetics. Tissues are placed in agar medium to determine fungal diversity via culturing and traditionally discarded once cultures are identified. Here we measured DNA quantity and quality of tissue samples that underwent fungal culture compared to fresh samples to determine their utility for genetics research.

We obtained samples from 15 bats collected for the Illinois Department of Public Health rabies surveillance program. We replicated biopsy procedures, collecting two $3 \mathrm{~mm}$ wing biopsies (Fig. 1a). DNA from one wing punch 
was extracted immediately, while the other was placed in either Sabourauds or Potato Dextrose Agar and stored at $7{ }^{\circ} \mathrm{C}$ for 2 weeks, replicating the culture protocol used for WNS detection (Fig. 1b). After 2 weeks, tissues were removed from agar and placed in $95 \%$ ethanol. Samples are hereafter referred to as 'fresh' and 'agar'.

We extracted DNA using a Quick gDNA miniprep kit (Zymo Research Corp., Irvine, CA, USA) following manufacturer's protocol. We eluted samples in $50 \mu \mathrm{L}$ volumes and estimated total DNA quantity and quality using a Nanodrop ${ }^{\circledR} 2000$ (Nanodrop Technologies, Wilmington, DE, USA). We measured total DNA yield and purity following methods of Green et al. (2013). We used Zymo Clean \& Concentrator kit (e.g. 'cleanup kit') to purify DNA and repeated the measurements and calculations for DNA quantity and quality. We verified recovery of host DNA by amplifying PCR products using microsatellite loci EF5, EF6, EF21 (Vonhof et al. 2002), B22, E24, and F19 (Castella and Ruedi 2000); products from fresh and agar tissues were within the expected size ranges.

We tested whether data met normality assumptions using a Kolmogorov-Smirnov test before comparing quantity and quality of DNA from fresh and agar samples, before and after cleanup. We tested for differences in DNA quantity and quality using a $t$ test and compared average concentrations and absorbance ratios between samples before and after cleanup using an ANOVA. All statistical analyses were completed in SAS v.9.3 (Cary, NC, USA).

All data met normality assumptions. We found no difference in DNA quantity between fresh and agar samples whether using DNA prior to cleanup $\left(\mathrm{t}_{28}=0.49\right.$; $P=0.63)$ or post cleanup $\left(\mathrm{t}_{28}=1.12 ; P=0.27\right)$. We also found no difference in DNA quality between fresh and agar samples prior to cleanup $\left(\mathrm{t}_{28}=-1.20 ; P=0.24\right)$ or post cleanup ( $\left.\mathrm{t}_{28}=1.56 ; P=0.13\right)$. Average DNA concentrations of both fresh and agar samples increased after cleanup kit processing (Table 1; $\mathrm{F}=8.3, P<0.01$ ) independent of whether they were fresh or agar. Purity ratios did not change after using the cleanup kit $(\mathrm{F}=0.72, P=0.49)$.

Host DNA can be recovered from wing biopsies placed in agar for $P$. destructans detection with no reduction in quantity or quality, opening research possibilities utilizing samples that would otherwise be discarded. The quantity of recovered DNA was suitable for downstream applications,
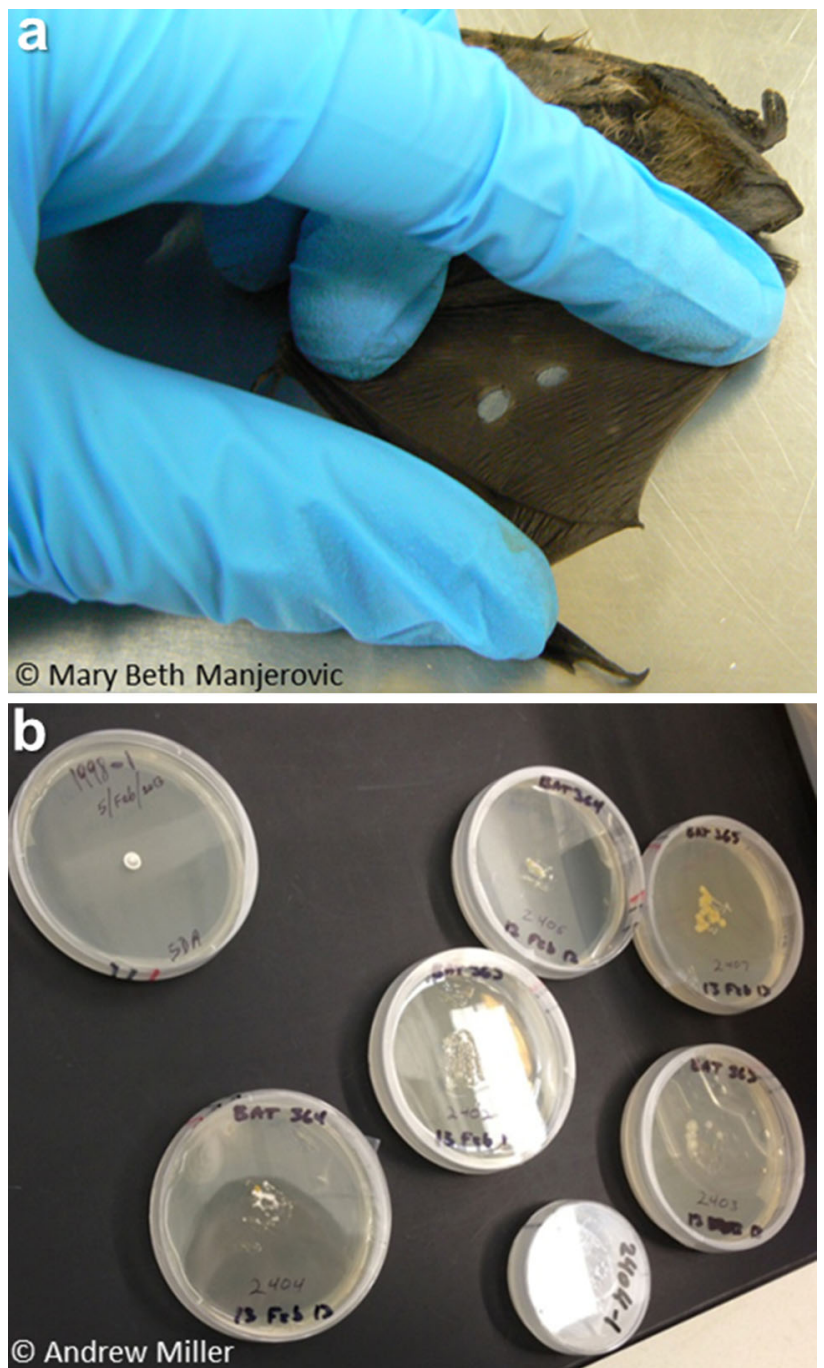

Fig. 1 a Wing biopsies taken from archived bat specimen. b Bat biopsy fungal cultures

including microsatellites, which have been amplified from bats using 10-25 ng of genomic DNA (Trujillo and Amelon 2009; Burns et al. 2012). DNA recovery of fresh and agar samples falls within the suitable range for microsatellite amplification even without post-extraction cleanup. The cleanup kit concentrated samples and should be used when working with small tissue samples because higher concentrations provide more control during downstream optimization.

Table 1 Total amount of DNA and purity ratios recovered from fresh and agar tissues

\begin{tabular}{|c|c|c|c|c|c|c|c|c|c|c|c|c|c|c|}
\hline & \multicolumn{7}{|c|}{ Fresh } & \multicolumn{7}{|c|}{ Agar } \\
\hline & $\mathrm{N}$ & DNA $(n g / \mu L)$ & SE & Range & Ratio & SE & Range & $\mathrm{N}$ & DNA $(n g / \mu L)$ & SE & Range & Ratio & SE & Range \\
\hline Pre-cleanup & 15 & 21.5 & 2.3 & $8.8-35.9$ & 1.7 & 0.03 & $1.4-1.9$ & 15 & 19.9 & 2.3 & $7.7-38.5$ & 1.8 & 0.04 & $1.6-2.0$ \\
\hline Post-cleanup & 15 & 43.4 & 6.3 & $15.2-102.5$ & 1.8 & 0.04 & $1.5-2.1$ & 15 & 33.7 & 5.9 & $6.7-73.8$ & 1.7 & 0.06 & $1.4-2.0$ \\
\hline
\end{tabular}

DNA (ng/ $\mu \mathrm{L})$ and purity ratios (ratio) are mean values of triplicate measurements with standard error (SE) 
Given the complexities involved with sampling bat populations, tissues collected for fungal detection represent a valuable genetic resource. Although molecular approaches require intensive sampling efforts, they allow researchers to ask new questions at resolutions previously unavailable (Kelly et al. 2010; Green et al. 2014). This research will pave the way for interdisciplinary partnerships to increase the knowledge produced from a single sample and for molecular approaches to enhance our understanding of WNS ecology (Archie et al. 2009).

Acknowledgments Research supported by USFWS Federal Aid in Wildlife Restoration Project (W-146-R) and University of Illinois Office of the Vice Chancellor for Research. The authors thank Daniel Raudabaugh and Nicole Conway for their assistance.

Open Access This article is distributed under the terms of the Creative Commons Attribution License which permits any use, distribution, and reproduction in any medium, provided the original author(s) and the source are credited.

\section{References}

Archie EA, Luikart G, Ezenwa VO (2009) Infecting epidemiology with genetics: a new frontier in disease ecology. Trends Ecol Evol 24:21-30. doi:10.1016/j.tree.2008.08.008

Burns LE, Broders HG, Frasier TR (2012) Characterization of 11 tetranucleotide microsatellite loci for the little brown bat (Myotis lucifugus) based on in silica genome sequences. Conserv Genet Resour 4:653-655. doi:10.1007/s12686-012-9615-8
Castella V, Ruedi M (2000) Characterization of highly variable microsatellite loci in the bat Myotis myotis (Chiroptera: Vespertilionidae). Mol Ecol Notes 9:993-1011

Green ML, Ting T, Manjerovic MB et al (2013) Noninvasive alternatives for DNA collection from threatened rodents. Nat Sci 5:18-26

Green ML, Manjerovic MB, Mateus-Pinilla NE, Novakofski J (2014) Genetic assignment tests reveal dispersal of white-tailed deer: implications for chronic wasting disease. J Mammal 95:646-654

Kelly AC, Mateus-Pinilla NE, Douglas M et al (2010) Utilizing disease surveillance to examine gene flow and dispersal in whitetailed deer. J Appl Ecol 47:1189-1198. doi:10.1111/j.1365-2664. 2010.01868.x

Speakman JR, Webb PI, Racey PA (1991) Effects of disturbance on the energy expenditure of hibernating bats. J Appl Ecol 28:1087-1104

Thomas DW, Dorais M, Bergeron JM (1990) Winter energy budgets and cost of arousals for hibernating little brown bats, Myotis lucifugus. J Mammal 71:475-479

Trujillo RG, Amelon SK (2009) Development of microsatellite markers in Myotis sodalis and cross-species amplification in $M$. gricescens, M. leibii, M. lucifugus, and $M$. septentrionalis. Conserv Genet 10:1965-1968. doi:10.1007/s10592-009-9869-1

US Fish and Wildlife Service (2011) A national plan for assisting states, federal agencies, and tribes in managing white-nose syndrome in bats. whitenosesyndrome.org/national-plan/whitenose-syndrome-national-plan. Accessed 11 Dec 2013

US Fish and Wildlife Service (2012) North American bat death toll exceeds 5.5 million from white-nose syndrome. http://www. batcon.org/pdfs/USFWS_WNS_Mortality_2012_NR_FINAL.pdf. Accessed 23 Sep 2013

Vonhof MJ, Davis CS, Fenton MB, Strobeck C (2002) Characterization of dinucleotide microsatellite loci in big brown bats (Eptesicus fuscus), and their use in other North American vespertilionid bats. Mol Ecol Notes 2:167-169. doi:10.1046/j. 1471-8286.2002.00189.x 